\title{
Žena u hrvatskoj migraciji stanovništva
}

Sažetak: Migracije (općenito) označavaju svaku promjenu mjesta boravka osobe koja migrira, većih i manjih grupa ili skupina ljudi. U povijesti istraživanja migracija vrlo je malo onih posvećenih istraživanjima žena u migracijskom procesu, ženama kao migranticama, vrijednostima i važnosti žena u migrantskim obiteljima i problemima s kojima se susreću žene migrantice u međunarodnom migracijskom vrtlogu. Uloga se žene u migracijskom procesu najčešće istraživala s aspekata gospodarskih promjena u društvu ili kroz ulogu djevojke, supruge, sestre, majke i gotovo uvijek zajedno s iseljavanjem muških članova obitelji. Različiti push i pull faktori utječu na ženu migranticu i njezinu odluku iseliti se ili ne iseliti iz sredine u kojoj je donedavno živjela. Faktori iseljavanja mogu se istraživati, analizirati i promatrati kroz individualnu, obiteljsku i društvenu razinu. Istraživanje mobilnosti žena, dilema dugogodišnje ,ženske nevidljivosti“, ženske marginalizacije i njihov formalni položaj u migracijskom procesu bili su primarni ciljevi istraživanja. U skladu s ciljevima istraživanja rad ukazuje na probleme i ulogu hrvatske žene u migracijskom procesu kroz socijalno-povijesnu dimenziju, daje pregled i analizu dostupnih demografskih pokazatelja o ženama migranticama, analitički predstavlja izabrane teorije migracije koje se dotiču žena migrantica, ukazuje na različite oblike migracija žena, detektira koji društveni status migrantice imaju, u najvećem broju slučajeva, u novoj domovini, obogaćuje postojeća saznanja i promišljanja, otvara nove vidike i ukazuje na novije spoznaje o ženama u migracijskom procesu te ujedno otvara mnoga nova pitanja za daljnja istraživanja feminizacije migracija.

Ključne riječi: žena iseljenica, vanjske migracije, spol, stanovništvo

\section{Uvod u ženske migracije}

Analizom pregleda općenito povijesti istraživanja migracija, primjećuje se da je mali broj istih posvećen migracijama žena. Žene su kao pripadnice „slabijeg spola“ najčešće promatrane kao ovisna pratnja 
muškarcima u migracijskim kretanjima, a manje kao samostalne ili primarne sudionice migracijskih procesa. Tek je u zadnjoj četvrtini 20. stoljeća više interesa i znatiželje $u$ istraživanju migracija posvećeno ženama kao migranticama, kao i njihovoj ulozi i važnosti u međunarodnim i globalnim migracijama stanovništva.

Prisutnost i pojavnost žena prije 20. stoljeća nije u dovoljnoj mjeri bila vidljiva u migracijskim procesima $i$ istraživanjima zbog različitih predodžaba o ženama migranticama kao isključivo pasivnim i uzdržavanim sudionicima migracijskih procesa od strane suprotnog spola. Kroz prizmu migracije stanovništva žene su promatrane isključivo u okvirima obiteljske migracije. Glavni i primarni migracijski protagonisti bili su mladi ekonomski motivirani muškarci, koji su trbuhom za kruhom i željom za boljim poslom i primanjima eventualno vodili i svoje supruge kao pratnju sebi u razvijenije zemlje svijeta. Ta i takva istraživanja zasjenila su brojnost i samostalnost žena u međunarodnim migracijskim kretanjima ${ }^{1}$. Tijekom posljednjih dva-tri desetljeća porastao je znanstveni interes za migrantice te se je pod utjecajem razvoja feminističke misli stao uvažavati spol odnosno rod kao važna analitička kategorija $\mathrm{u}$ istraživanju migracija ${ }^{2}$. Temeljem kategorije roda, kao postojeće kulturne i društvene determinante, razlikuju se migracijska iskustva muškaraca i žena te se pokušava zaobići stereotipni i pojednostavljeni pristup i promišljanja o ženama kao migranticama općenito. Isto se nastoji postići i bolje razumijevanje migracijskih procesa i njihove kompleksnosti uključivši i uvažavajući i žene kao primarne migrantice na globalnoj razini.

Namjera je ovoga rada ujedno i upozoriti na mnoga pitanja o statusu hrvatske žene u novoj/staroj domovini te ih potaknuti. Također, smatra se važnim upozoriti na potrebe pokretanja rasprava na svim društvenim sferama s ciljem poboljšanja zaštite prava žena migrantica te pokušati skrenuti pažnju na važnost njihove sigurnosti ako je ona upitna te osvijestiti važnost potrebe za osiguravanjem sredstava pomoći šireg aspekta različitog tipa za žene migrantice.

\footnotetext{
${ }^{1}$ Mirjana Morokvašić, „Gendering Migration,“ Migracijske i etničke teme, br. 30/3 (2014): 355-378

2 Sanja Cukut Krilić, Spol in migracija: Izkušnje žensk kot akterk migracij (Ljubljana: Inštitut za slovensko izseljenstvo in migracije ZRC SAZU, 2009), 187.; Klara Kožar Rosulnik, „Ženske in migracije,“ Andragoška spoznanja, br. 21/3 (2015): 23-37.
} 


\section{Teorijska promišljanja koja se dotiču ženskih migracija}

Uvažena hrvatska demografkinja Wertheimer-Baletić ${ }^{3}$ pod vanjskom migracijom podrazumijeva migracije s polazištem unutar granica, a odredište izvan granica određene zemlje. Ona ${ }^{4}$ naglašava da su međudržavne migracije radne snage, u kojoj su prisutne i žene, spontano reagiranje na postojeće neusklađenosti ponude i potražnje i bile one trajne ili privremene, regulirane su mjerama koje država poduzima u okviru određene gospodarske ili drugih politika u pogledu obujma i strukture migranata. Demografske posljedice vanjskih migracija očituju se istodobno u zemlji emigracije i zemlji imigracije, djeluju na komponente prirodnog kretanja, na stopu promjene stanovništva i broj stanovnika kao i na promjene društveno-gospodarskih struktura stanovništva. Wertheimer-Baletićs upozorava i na to da su vanjske migracije stanovništva skupe, zahtijevaju veće individualne i društvene troškove i odnose sa sobom prethodne investicije društva i obitelji, a pogotovo ako emigriraju žene i visokoobrazovane osobe.

Demograf Akrap ${ }^{6}$ također upozorava na to da su vanjske migracije jak destabilizirajući čimbenik razvoja hrvatskog stanovništva u zemlji čiji su učinci dalekosežni (gubitak najvitalnijeg dijela stanovništva, pad nataliteta, itd.). Država podrijetla stanovništva gubi proizvođače i stanovništvo koje pridonosi socijalnoj efikasnosti i sigurnosti u aspektima poput zdravstva, mirovina ...

Migrantske mreže ljudi međusobno povezanih obiteljskim, prijateljskim ili inim vezama od pomoći su migrantima u svakodnevnom životu, a ponajviše ženama u novoj sredini. Ideja mreža migranata (muških i ženskih) generalizirana je u teoriji transnacionalnih socijalnih prostora ${ }^{7}$. Teorija priznaje postojanje različitih migracija vezanih prekograničnim vezama između pojedinaca (muškaraca i žena) i grupa. Nova ekonomska teorija migracije ${ }^{8}$ ukazuje na to da se odluke o migraciji

\footnotetext{
${ }^{3}$ Alica Wertheimer-Baletić, Stanovništvo i razvoj (Zagreb: Mate, 1999), 655.

${ }^{4}$ Wertheimer-Baletić, Stanovništvo i razvoj, 453-536.

${ }^{5}$ Wertheimer-Baletić, Stanovništvo i razvoj, 78-289.

${ }^{6}$ Anđelko Akrap, Jakov Gelo i Marinko Grizelj, "'Broj prisutnog stanovništva Republike Hrvatske i županija po dobi i spolu od popisa stanovništva 1991.-1998. godine," Društvena istraživanja, 8, br. 5-6 (43-44) (1999): 679-723.

7 Thomas Faist, The Volume and Dynamics of International Migration and Transnational Social Spaces (Oxford: Oxford University Press, 2000), 793.

8 Oded Stark i David E. Bloom, „The new economics of labor migration,“ American Economic Review, br. 75 (2) (1985): 173-178.; Oded Stark, „Tales of Migration without Wage Differentials: Individual, Family and Community Contexts, “ ZEF Discussion Paper on Development Policy Zentrum für Entwicklungsforschung, br. 73 (2003): 1-15.
} 
vežu uz kućanstva, a ne isključivo uz pojedinca. To se novo otkriće podudara s promatranjem migracijskog procesa koji karakterizira vidljive obiteljske obrasce i muškarce, ali i žene što su zaključili i ekonomisti ${ }^{9}$ i demografi ${ }^{10}$.

U suodnosu određenog interesa, u svakoj se teoriji detektirala i moguća feminizacija migracija. Promatramo li pak pojavu migracija šire, žene su generalno mobilnije od muškaraca ${ }^{11}$. Permanentna prisutnost žena u migracijskim kretanjima pokazuje određenu zrelost migracijskog procesa kao i određenu kvalitativnu promjenu ako žene migriraju kao primarne migrantice, nezavisne akterice za poslom ili kao glava obitelji.

\section{Feminizacija migracija}

Feminizacija migracija nezaobilazan je pojam kad je riječ o globalizaciji i migraciji ${ }^{12}$, a ukazuje na brojčani porast broja žena u odnosu na muškarce migrante te na promjene u kvaliteti migracijskih tokova, stupanj zrelosti migracija i podrijetlo migranata.

Migracijama žena i pojavom žena kao primarnih migrantica preokrenuo se dosadašnji trend migracija kada su muškarci bili glavni akteri i sudionici migracijskog procesa te osobe koje osiguravaju skrb i primanja za sebe i obitelj.

Vidljivost žena u migracijskom procesu i uloga koju imaju kao glavne protagonistice migracija karakteristični su za razvijene dijelove svijeta te za određena zanimanja i poslove koje žene kao migrantice obavljaju. Morokvašić ${ }^{13}$ ističe da su migracije žena rezultat vezan i uz ponudu radnih mjesta i tržište rada te da ih teško nalazimo primjerice u građevinskom sektoru.

Činjenica je da su žene i prije dosadašnjeg trenda iseljavale prema razvijenijim zemljama svijeta te da su i mnoge u tim zemljama i ra-

\footnotetext{
9 Jacob Mincer, „Family Migration Decisions,“ Journal of Political Economy, br. 86(5) (1978): 749-773.

10 Stephen Castles i Mark J. Miller, The Age of Migration, 4th ed. (London: Palgrave MacMillan, 1993), 326.

${ }^{11}$ Ernest Georg Ravenstein, „The Laws of Migration,“ Journal of the Royal Statistical Society, br. 48, (1885): 167-235.

${ }^{12}$ Castles i Miller, The Age of Migration, 75-94.

${ }_{13}$ Mirjana Morokvašić, „Feminizacija migracija?““ Centre National de la Recherche Scientifique (CNRS) Institut des Sciences sociales du Politique (ISP), (2010): 25-52, accessed May 23, 2020, http://www.doiserbia.nb.rs/img/doi/0038-982X/2010/0038-982X1002025M. pdf
} 
dile, no njihova je radna aktivnost ostala neprimijećena, nezabilježena i nevidljiva u literaturi. Svjesnost da postoje različiti oblici migracija žena, a koji mogu biti i najvećim dijelom u suodnosu s podrijetlom, postignutim kvalifikacijama, školovanjem, prilikama u zemlji iz koje žene potječu i slično, ženske migracije dijelimo na bračne migracije, migracije zbog posla (žene radnice), trgovanje ženama i prisilne migracije žena.

Ženske migracije donedavno su bile marginalna tema, a danas su se nametnule kao istraživačka tema koja će pridonijeti zrelijem i što boljem rasvjetljavanju kompleksne teme migracijskog procesa.

Nastavno na suodnos hrvatskog slučaja i feminizaciju migracija, razvoju istraživačke teme ženskih migracija pogodovao je i ulazak Republike Hrvatske u Europsku uniju 1. srpnja 2013. godine te otvaranje tržišta rada u drugim članicama kada poveći broj žena odlazi ili planira odlazak iz Republike Hrvatske.

Broj iseljenih žena iz Republike Hrvatske u razdoblju 2002. - 2018. godine prema podatcima Državnog zavoda za statistiku Republike Hrvatske

\begin{tabular}{|l|c|}
\hline \multicolumn{1}{|c|}{ Godina } & Broj iseljenih žena \\
\hline 2002. & 5.183 \\
\hline 2003. & 3.128 \\
\hline 2004. & 3.366 \\
\hline 2005. & 2.994 \\
\hline 2006. & 3.852 \\
\hline 2007. & 4.462 \\
\hline 2008. & 3.793 \\
\hline 2009. & 4.985 \\
\hline 2010. & 5.022 \\
\hline 2011. & 5.931 \\
\hline 2012. & 6.496 \\
\hline 2013. & 7.360 \\
\hline 2014. & 9.256 \\
\hline 2015. & 13.715 \\
\hline 2016. & 16.733 \\
\hline 2017. & 21.138 \\
\hline 2018. & 17.759 \\
\hline Ukupno & $\mathbf{1 3 5 . 1 7 3}$ \\
\hline
\end{tabular}

Tablica 1 Broj iseljenih žena iz Republike Hrvatske u razdoblju 2002. - 2018. godine Izvor: http://www.dzs.hr, zadnji pregled 20. siječnja 2020. 
Analiza podataka Državnog zavoda za statistiku Republike Hrvatske, kategorije ukupne emigracije stanovništva prema spolu pokazuje kako je iz Republike Hrvatske u razdoblju od 2002. do 2018. godine ukupno iselilo 135173 žena u zemlje Europske unije (tablica 1). Podatci pokazuju kako broj iseljenih žena iz Republike Hrvatske 2013. godine bilježi veći porast nakon ulaska Republike Hrvatske u Europsku uniju. Također, u posljednjih šest godina broj iseljenih žena iz Republike Hrvatske značajno je povećan zbog loše gospodarske situacije u zemlji, gubitka radnih mjesta, neotvaranja novih itd., što će u konačnici dugoročno polučiti negativne posljedice za hrvatsko društvo i gospodarstvo. Točni podatci o destinacijama kamo su popisane žene iselile iz Republike Hrvatske nisu poznati i dostupni iz nekoliko razloga. Prvi je to što Republika Hrvatska nema Registar stanovništva, nužan za takvu vrstu podataka i spoznaja. Isto tako, praksa pokazuje kako migrantice nakon određenog razdoblja mijenjaju prvotno mjesto imigracije zbog novih privlačnih (pull čimbenika) na licu mjesta nove destinacije.

\section{Obiteljski i društveni status žena migrantica u novoj domovini}

Na ženu kao glavnu aktericu i/ili primarnu migranticu utječu, uz opće poznate push i pull čimbenike, i individualni, obiteljski i društveni čimbenici. Potisni čimbenici (push čimbenici) potiču migraciju i prisutni su u mjestu prebivališta, a privlačni (pull čimbenici) u potencijalnim destinacijama prema kojima se kreću migrantice. Neki od potisnih čimbenika su: nezaposlenost, nezadovoljstvo na poslu vezano uz napredovanje u struci, uvjeti rada, niske plaće, političke, etničke, rasne ili vjerske netrpeljivosti, prirodne katastrofe i ratovi. S druge strane, privlačni faktori mogu biti bolje prilike za zaposlenje i zaradu, mogućnost napredovanja u struci, viši standard obitelji ili pojedinca, bolji uvjeti života, politička, vjerska i rasna tolerancija. Svi navedeni čimbenici utječu i na zemlju iz koje žena potječe i na zemlju u koju žena seli.

Individualni čimbenici uključuju dob, spol, rasu/nacionalnost, urbano/ruralno podrijetlo, bračno stanje, reproduktivni status (s djecom ili bez djece), ulogu u obitelji (supruga, kći, majka, baka), položaj u obitelji, obrazovni status, profesionalne vještine, radno iskustvo i položaj klase ${ }^{14}$.

\footnotetext{
${ }^{14}$ Rebeka Mesarić Žabčić, „Women in the migrational process,“ Croatian Studies Review,
} vol. 13, br. 1 (2018): 47-69. 
Obiteljski čimbenici uključuju veličinu, dob/spolnu strukturu, stupanj životnog ciklusa, status u obitelji (samohrani roditelj, oba roditelja, itd.), te klase u obitelji ${ }^{15}$.

Društveni čimbenici uključuju sve one društvene norme i kulturne vrijednosti koje određuju hoće li žena moći iseliti ili ne i, ako može (zbog rada ili spajanje obitelji), s kim (sama ili s obitelji) ${ }^{16}$.

Udio žena u migracijskom procesu osobito je visok u tradicionalnim zemljama imigracije (Australija, Kanada i Sjedinjene Države) gdje su žene više od desetljeća primarne migrantice i glavne akterice migracijskog procesa.

\section{Žene kao povratne migrantice}

I povratna migracija sastavni je dio migracijskog procesa u čijem su fokusu i ženske migracije, misleći pri tom na žene migrantice kao samostalne akterice povratka u domovinu ili kao one koje su povratak realizirale zajedno sa svojom obitelji. Sustavna istraživanja i analize žena povratnica u Republiku Hrvatsku nedostaju zbog pomanjkanja preciznih statistika o povratnim migracijama u Republici Hrvatskoj. Poteškoće u njihovu statističkom praćenju postoje i na svjetskoj razini gdje pristupi povratnim migracijama, načini njihova evidentiranja te kategorizacija povratnih migranata nisu usklađeni ${ }^{17}$.

Realizacija povratka u zemlju podrijetla nešto je o čemu većina migranata razmišlja za vrijeme emigracije ${ }^{18}$.

Tijekom i nakon realizacije dobrovoljnog povratka, ako se ostvari, počinje proces prilagodbe novoj/staroj okolini i proces uključivanja u društveni, kulturni i gospodarski život zemlje podrijetla koji neizostavno pada pod utjecaj različitih čimbenika, od društvenog statusa i osobnih iskustava prije migriranja, samog migracijskog iskustva te uvjeta i realizacije povratka.

Izvjesno je da su žene migrantice tijekom svog migracijskog iskustva prošle kroz proces kulturoloških promjena i da se mogu vratiti

\footnotetext{
${ }^{15}$ Mesarić Žabčić, „Women in the migrational process,“ 47-69.

${ }^{16}$ Monica Boyd i Elizabeth Grieco, „Women and Migration: Incorporating Gender International Migration Theory,“ Journal of Migration Policy Institute (2003): 1, accessed April 24, 2020, http://www.migrationpolicy.org/article/women-and-migration-incorporating-genderinternational-migration-theory.; Mesarić Žabčić, „Women in the migrational process,“ 47-69.

17 OECD, „International Migration Outlook“ Annual Report OECD, (2008): 161-222.

18 Jørgen Carling, Marta Bolognani i Marta Bivand Erdal „Possibilities and Realities of Return Migration,“ (Oslo: Peace Research Institute, 2015): 44.
} 
i s novim idejama, stečenim znanjem, vještinama, vrijednostima te različitim oblicima kapitala što im omogućuje i/ili olakšava realizaciju različitih idejnih planova i aktivnosti različitog tipa u matičnoj zemlji.

Migrantska iskustva žena oblikovana su različitim čimbenicima, identitetima te životnim i migracijskim okolnostima pa su, shodno tome, i povratnička iskustva također složena, ovisno o želji i motivima povratka, trajanju migracije, pripremi i realizaciji povratka, trenutnim političkim, gospodarskim i društvenim prilikama u zemlji podrijetla, kao i stečenim resursima (financijski, ljudski, socijalni kapital) ${ }^{19}$.

Istraživana tema ovoga rada može predstavljati i zasebno područje istraživanja u koje se može uključiti i širi aspekt analiza i promišljanja, a isto tako može sadržavati i zajedničke dodirne točke koje pak otvaraju posebno istraživačko područje vezano uz povratne migracije žena i njihov poduzetnički potencijal u domovini. Riječ je, još uvijek, o nedovoljno istraženoj temi u okviru suvremene migracijske kompleksnosti koja se polako probija na repertoar hrvatskih migracijskih istraživanja.

\section{Zaključak}

Žene migrantice danas su na globalnoj razini primarne, samostalne i aktivne akterice migracija. Kroz prizmu migracijskog procesa žene migrantice vođene su vlastitim ciljevima i planovima. Na tome tragu istraživanja, ženama migranticama pristupa se kao aktivnim sudionicama migracijskog procesa koje vrlo svjesno, odlučno i samostalno odlučuju o vlastitim migracijskim kretanjima. Migracija im služi i kao način stjecanja potrebnog kapitala za ostvarenje i realizaciju vlastitih ideja i vještina. Migracije i mobilnost žena u globalnim migracijskim kretanjima pokazuju kako su žene kao migrantice prisutne i vidljive kroz uloge različitog tipa, bilo da su vidljive na individualnoj razini u ulozi kćeri, supruge, majke, bake, ili šire na društvenoj razini u vidu profesionalnog usavršavanja ili pak kao radnice, azilantice i sl.

Sukladno tome, čimbenici iseljavanja mogu se istraživati, analizirati i promatrati kroz individualnu, obiteljsku i društvenu razinu i još su uvijek nedovoljno istraženi u Republici Hrvatskoj.

\footnotetext{
19 Jean-Pierre Cassarino, „Theorising Return Migration: The Conceptual Approach to Return Migrants Revisited,“ International Journal on Multicultural Societies, br. 6/, (2004): 270-272.; Jasna Čapo Žmegač, „Različiti pristupi povratnim migracijama: primjer Hrvatske,“ Studia ethnologica Croatica, br. 22 (2010): 29-30.
} 
Mnoge žene migrantice ostvaruju osobni poslovni uspjeh te poboljšavaju osobnu poziciju i status u novom/starom društvu. Kod žena migrantica moguć je pozitivan utjecaj povratničkih inicijativa na gospodarski i kulturni razvoj domicilne zemlje. U Republici Hrvatskoj nedostaju istraživanja koja donose promišljanja i spoznaje o mogućnostima i doprinosu žena migrantica povratnica u gospodarskom razvoju zemlje podrijetla, kao i svim problemima s kojima se žene povratnice suočavaju.

Analiza migracijskih procesa u kojima su glavne i primarne migrantice žene, kao i istraživanje difuznije cirkulacije žena smatraju se vrijednim doprinosom razumijevanju migracija i migracijskih tokova. Promišljanja o ženskim migracijama potiču i stvaraju nove zaključke te pridonose širem razumijevanju feminizacije migracija što neizostavno otvara mnoga pitanja te daje nove poticaje za daljnja istraživanja tog tipa.

\section{Literatura}

Akrap, Anđelko, Jakov Gelo i Marinko Grizelj. „Broj prisutnog stanovništva Republike Hrvatske i županija po dobi i spolu od popisa stanovništva 1991. do 1998. godine.“ Društvena istraživanja 8, br. 5-6 (43-44) (1999): 679-723.

Blanchflower, David G. i Andrew J. Oswald. „What Makes an Entrepreneur?.“ University of Chicago Press: Journal of Labor Economics, br. 16/1 (1998): $1-28$.

Boyd, Monica i Elizabeth Grieco. „Women and Migration: Incorporating Gender International Migration Theory.“ Journal of Migration Policy Institute (2003): 1, accessed April 24, 2020, http://www.migrationpolicy.org/article/womenand-migration-incorporating-gender-international-migration-theory.

Carling, Jørgen, Marta Bolognani i Marta Bivand Erdal. Possibilities and Realities of Return Migration. Oslo: Peace Research Institute, 2015.

Cassarino, Jean-Pierre. „Theorising Return Migration: The Conceptual Approach to Return Migrants Revisited.“ International Journal on Multicultural Societies, br. 6/2 (2004): 270-272.

Castles, Stephen. „International Migration at the Beginning of the Twenty-First Century: Global Trends and Issues.“ Wiley Press, NY: International Social Science Journal, br. 52/165 (2000): 269-281.

Castles, Stephen i Mark J. Miller. The Age of Migration, 4th ed. London: Palgrave MacMillan, 1993.

Castro, Luis. J. i Andrei Rogers. „Patterns of Family Migration: Two Methodological Approaches.“ International Institute for Applied Systems Analysis, Laxenburg, Austria: Environment and Planning A, br. 15(2) (1983): 237-254. 
Cukut Krilić, Sanja. Spol in migracija: Izkušnje žensk kot akterk migracij. Ljubljana: Inštitut za slovensko izseljenstvo in migracije ZRC SAZU, 2009).

Čapo Žmegač, Jasna. „Različiti pristupi povratnim migracijama: primjer Hrvatske.“ Studia ethnologica Croatica, br. 22, (2010): 11-38.

Démurger, Sylvie, Hui Xu. „Return Migrants: The Rise of New Entrepreneurs in Rural China." Springer, World Development, br. 39/10 (2011): 1847-1861.

Dustmann, Christian, Oliver Kirchkamp. „The optimal migration duration and activity choice after re-migration." Elsevier, Amsterdam: Journal of Development Economics, br. 67, (2002): 351-372.

Faist, Thomas. The Volume and Dynamics of International Migration and Transnational Social Spaces. Oxford: Oxford University Press, 2000.

Kožar Rosulnik, Klara. „Ženske in migracije.“ Andragoška spoznanja, br. 21/3 (2015): 23-37.

Mesarić Žabčić, Rebeka. „Women in the migrational process.“ Croatian Studies Review, vol. 13, br. 1 (2018): 47-69.

Mincer, Jacob. „Family Migration Decisions.“ University of Chicago Press: Journal of Political Economy, br. 86(5) (1978): 749-743.

Morokvašić, Marjana. „Feminizacija migracija?““ Centre National de la Recherche Scientifique (CNRS) Institut des Sciences sociales du Politique (ISP) (2010): 25-52, accessed May 23, 2020, http://www.doiserbia.nb.rs/img/doi/0038982X/2010/0038-982X1002025M.pdf

Morokvašić, Mirjana. „Gendering Migration.“ Migracijske i etničke teme, br. 30/3 (2014): 355-378.

OECD. „International Migration Outlook“ Annual Report OECD (2008): 161-222.

Ravenstein, Ernest Georg. „The Laws of Migartion.“ Journal of the Royal Statistical Society, br. 48 (1885): 167-253.

Stark, Oded i David E. Bloom. „The new economics of labor migration.“ American Economic Review, br. 75 (2) (1985): 173-178.

Stark, Oded. „Tales of Migration without Wage Differentials: Individual, Family and Community Contexts. “ ZEF Discussion Paper on Development Policy Zentrum für Entwicklungsforschung, br. 73 (2003): 1-15.

Wahba, Jackline i Yves Zenou. „Out of Sight, Out of Mind: Migration, Entrepreneurship and Social Capital.“ Bonn-Discussion Paper, br. 4541 (2009): 1-28.

Wertheimer-Baletić, Alica. Stanovništvo i razvoj. Zagreb: Mate, 1999.

Zlotnik, Hania. „The Global Dimensions of Female Migration.“ Migration Policy Institute (2003): 1, accessed May 26 2020. http://www.migrationpolicy.org/ article/global-dimensions-female-migration.

\section{Izvori}

http://www.dzs.hr, accessed Januar 20, 2020.

\section{Woman in Croatian Population Migration}

Summary: Migrations (generally) mean any change in the place of residence of a migrant or larger and smaller group of people. In the history of migration research, 
just few researches have been devoted to the research of women in the migration process, women as migrants, the values and importance of women in migrant families and the problems women migrants face in the international migratory whirlwind. The role of woman in the migration process is most often studied from the aspect of economic change in society or through the role of a girl, a wife, a sister, a mother, and together with the emigration of male family members. Different push and pull factors affect a migrant woman and her decision to move or not to move away from the environment she has recently lived in. Emigration factors can be explored, analyzed and observed on individual, family and social levels. Research on women's mobility, the dilemma of long-standing ,female invisibility" and their formal position have set goals for the starting point of this work. The paper points to the problems and role of women in the migration process through the socio-historical dimension, provides an overview and analysis of available demographic indicators on migrant women, analytically represents selected migration theories related to migrant women, points to different forms of women migration, detects the social status migrants have in most cases in new homeland, enriches existing knowledge and reflection, opens up new perspectives and points to newer meanings of women in the migration process and opens up many new issues for further research into feminisation of migration.

Keywords: women immigrants, foreign migration, gender, population 